\title{
Jurisprudence As An Undergraduate Study
}

ПHERE seem to be three attitudes toward jurisprudence: ${ }^{1}$ I. The first entirely ignores it for law-school purposes, regarding it as an adornment merely-fanciful, unreal, or unnecessary, and when not positively harmful, as serving only a decorative purpose. $^{2}$ This is an extreme position which rarely has found expression. But it cannot be overlooked that there is a not inconsiderable body of silent opinion which is latently hostile to jurisprudence both in name and in content. Jurisprudence stinks in the nostrils not so much of the practicing lawyer as of the professional law teacher. This negative opposition is explainable chiefly on three grounds: (1) as a positivist hang-over of the reaction against natural law; (2) as a part of the empirical tradition of the common law; (3) as a purely American bias founded on the belief that knowledge is unattainable except by the kindergarten method of concrete representation.

As against all this, it may be advanced as a fundamental and unassailable proposition that if there is such a body of knowledge as jurisprudence, that is, if it is not a pseudo-science as astrology and magic are reputed to be, then it must be taught and studied in law schools of the university type. It follows, also, that for types of schools which rest their mission on emphasizing the practical and utilitarian in legal education, jurisprudence is quite as dispensable as conic sections in the training of a flour merchant. ${ }^{3}$

1 The term jurisprudence is here used in a wide, and no doubt inaccurate, sense as a convenient ensemble of all abstract (general) and non-utilitarian law subjects, including, for example, Roman law, legal history, legal ethics, comparative law, legislation, and analytical jurisprudence. But even this wide sense excludes economics, politics, ethics, etc. The doctrinal treat- ment of such topics does not belong to the law school. In a stricter (though not the most limited) sense it is synonymous with science of law, the general aspect of legal facts.

2 "The really profound changes in human life all have their tutimate origin in knowledge pursued for its own sake. . . . The importance which the science of electro-magnetism has since assumed in every department of human life is not due to the superior practical bias of Europeans, but to the fact that in the West, electric and magnetic phenomena were studied by men who were dominated by abstract theoretic interests": Whitehead, "An Introduction to Mathematics," pp. 32-33.

'A boatswain's mate may be a very capable seaman even though he cannot do a problem in long division; but it is interesting to note the recent statement (Classical Journal, Dec. 1919) of an eminent London banker and Homeric scholar (Walter Leaf) that when employing 2 bank clerk, other things being equal, he would give preference to one who had studied the classics, on the ground that in the unexpected stresses of life, the classical student would bring to bear upon the situation a mental poise which the other could not call to his aid. It still remains true, however, that the best law schools graduate men who have not even the Roman law inproficiency of Robert Louis Stevenson, who had learned, however, enough of it to be informed that emphyteusis is not a disease and that stillicide is not a crime (Balfour, Life of Robert Louis Stevenson, I, 83). 
II. Another attitude takes account of jurisprudence and is willing to admit its scientific reality and its possible value, but is unwilling to admit it as an undergraduate law study. Two alternatives seem to be presented:

A. That jurisprudence may be taught in the college of liberal arts either (a) preceding the law studies or (b) concurrently with law studies.

One of the objections on record to the teaching of jurisprudence courses in law schools is that the materials have not the pedagogical interest produced by the case-book of dogmatic law. ${ }^{4}$ In the first place, it is not entirely clear that the assertion is well founded. That the materials are likely to be different is clear enough, and yet they need not be different. There may just as well be case-books on analytical jurisprudence, formal jurisprudence, historical jurisprudence, philosophy of law, etc., etc., as of contracts, torts, equity, etc., etc. In the next place, taking the assumption as true, it cannot stand as a valid scientific objection. Whether mathematics or the dead languages should be taught, would hardly be made to depend on their spontaneous appeal to the average mind in competition with the laboratory or descriptive arts and sciences. Likewise, the question whether an abstract concept, let us say, or definition of law, is as interesting as a murder case would seem unworthy of consideration.

But the case-book has become a fetish. Law-school teachers have become so impressed with its value (and we do not minimize it) that the erroneous belief has spread that for the law, inductive materials and the inductive method are the sole source of knowledge. "The principle "ipsis consuescere rebus" has been overworked. At this juncture, let us inquire what quantum of what we believe and act on in life, is derived from living experience alone? It would not suffice to bring one through the morning meal! The case-book has mentally reacted not only on the teacher but also on the pupil. The pupil must have his ideas dramatized. $\mathrm{He}$ is essentially unable after about two years' experience with the moving pictures of the case-book method to read a code, or any summary statement of legal doctrine. His mind becomes

4 Ernst Freund, "Correlation of Work for Higher Degrees," 11 Illinois Law Review, 301, 309-10.

5 So powerful is this heresy that even those who least accept it acknowledge its pragmatic authority. Two independent case-books are in the course of preparation on Roman law. One of these will be published by Charles P. Sherman, D. C. L., who least of all can be charged with case-book infatuation. 
warped to the habit of a single mental calisthenic. ${ }^{6} \mathrm{He}$ can climb up a ladder but cannot climb down again. The development of the exclusive case-book bent of mind is no doubt unfavorable for the prosecution of jurisprudence studies, but it does not follow that the overemphasis of one method, valuable enough in its time, its place, and its purpose, should furnish the ground for excluding necessary and essential training in other directions. We admit, therefore, that experience is better than advice, but we insist that life cannot be lived based solely on personal experience. So, also, in the law, it is not either possible or essential to go over the whole ground case by case before one may be expected to know anything about it. As between concrete knowledge and abstract knowledge, we have no reason to suppose that one is more valauble than the other so long as it is knowledge. And as to the question of the inductive method as against the deductive mtthod, it is a commonplace to repeat here, that neither is exclusive of the other. With reference to the specific problem, we can find no reasonable ground to believe that, if the underlying data are understood, an abstract method, considered in all aspects of what is to be accomplished, is not pedagogically and essentially as serviceable as the sometimes tedious, time-ensuing inductive or concrete method. It is precisely because the underlying data are not, and cannot be, understood by the undergraduate student in the college of liberal arts, that the teaching of jurisprudence courses must be regarded as ineffective in that setting, as a preliminary to professional law study. The teaching of jurisprudence in liberal arts colleges concurrent with professional law study is also highly objectionable on account of the mechanical difficulties of such a plan. Moreover, such a divorcement is wholly unnecessary.

$B$. The other alternative is that jurisprudence may be taught as a post-graduate study. ${ }^{7}$ According to this view, the general professional curriculum is not to be diluted with formal courses in legal science, but the courses in contracts, torts, etc., will do the work of courses in philosophy of law, comparative law, criminology, historical jurisprudence, Roman law, etc. etc. Some of the objections to this solution are as follows:

1. It cannot be justified except on the belief that jurisprudence is not an essential part of a lawyer's professional equipment. It

- Cf. John H. Wigmore, Nova Methodus Discendae Docendaeque Jurispriedentiae, 30 Harvard Law Review, 812.

$\checkmark$ Centennial History of the Harvard Law School (1817-1917), pp. 167 seq. 
fosters the "tradesman" point of view in legal education, when a new era demands a high degree not only of technical, utilitarian equipment, but of cultural training to prepare the undergraduate for a truly learned profession fit to stand alongside the rising standards of medicine, engineering, and other arts.

2. The "percolation" process of jurisprudence by which the law teacher who is already teaching a half-dozen dogmatic law subjects (in each of which presumably he is a specialist!), is to fertilize the ground by his good-natured recollections of postgraduate achievement in philosophy of law, Roman law, criminology, comparative law, etc., etc., is loosely unscientific and impossible.

3. A graduate school in jurisprudence does not meet the point. A handful of graduate students out of thousands who are studying law in America at any one time will not serve to put the law on the same scientific plane as, for example, the medical profession. ${ }^{8}$ There must be direct action, and this direct action must reach the undergraduate by allotting a certain amount of work in legal science to supplement and inform his studies of dogmatic law. How much or how little of "jurisprudence" shall be required is not here under discussion, except to say that it need not necessarily include the whole field of legal science any more than the whole field is required in the dogmatic courses. Mohammadan law, for example, might be generally excluded notwithstanding its scientific value. On the other hand, mere infusions of legal science will not do. Formal courses to a certain extent must be provided and earnestly carried out in the same thoroughgoing way, so far as possible, as courses in contracts or torts. A great deal no doubt is yet to be discovered about the most efficient methods of giving jurisprudence courses, but with the rising standards of entrance requirements in law schools, defective methods are not of capital importance. Nor is the graduate school in jurisprudence to be superseded. At least three or four such schools should exist in America; but a graduate school in jurisprudence worthy of the name can hardly be founded on an undergraduate school which excludes all formal courses in legal science. If the jurisprudence courses are given for the first time in the fourth year (based on a three-year course), as to those courses, at least, the label "graduate" study is simply a misnomer.

Bn the ten-year period 1909-10-1918-9 there were 46 graduate students enrolled in the Harvard Law School. The number of undergraduate students in the same school in the same period is reckoned in thousands. 
Would a student who had worked in Roman law, for example, for only a few months be prepared for a critical exploration of a Tribonianism? Clearly not, and if not, where and when are the graduate studies to be pursued?

The question is one of policy and of degree. If legal science is to be only for the graduate student, then it is not material that the undergraduate gets only a little legal science in an accidental way. But if, as we believe, the content and range of the courses given to the undergraduate must break the bounds of a strictly empirical tradition, not to be abandoned, but to be scientifically strengthened, then it will not do for the future to say that the student shall be limited to the training typically associated with the case method diluted with infusions of legal science.

III. The last methodical possibility has already been stated jurisprudence courses may be offered to undergraduates. ${ }^{9}$

The Redlich Report recommended an introductory course in legal science and also a comprehensive course for later study. What Professor Redlich had in mind for the substance of an introductory course is typical of the continental "juristic survey," often called "encyclopedia." These courses are a minimum which falls below what is necessary for a learned profession and for a university law school. Analytical and formal jurisprudence should thoroughly impregnate the whole curriculum, first by means of one or more introductory courses, then by a formal course, and throughout by concrete application. What progress can be made in the first-year subject of torts if the student flounders through not understanding the nature of a jural nexus? What understanding does he bring to his discussion of cases in chattels if he cannot distinguish a right in rem from a right in personam ${ }^{10}$ It is idle to suppose that the instructor can interrupt the busy hour of classroom work to make the explanation, or that he will succeed if he attempts it.

To this minimum we would add a thoroughgoing course in the theory of law and the sources, and at least one course in either concrete or abstract comparative law, or both. Beyond that point the ground is debatable and the solution will depend on the length

9 For contrasted views, see Wesley N. Hohfeld, A Vital School of Jurisprudence and Law: Address to Association of American Law Schools, December, 1914; and Powell, Law as a University Study, Columbia University Quarterly, March, 1917.

${ }_{10}$ For an illustration, out of hundreds which may be quickly instanced, of the necessity of the distinction for clear understanding of the case, see Johnson v. Stear (1863) 15 C. B. (N. S.) 360, 143 Eng. Rep. R. 812 (Gray's Cases on Property, Vol. I, p. 213). 
of the undergraduate course, and the general standards and equipment of the school. Differences of view will arise also as to elective and non-elective courses. We take it for granted that all university law schools will admit in varying proportions and under varying methods such auxiliaries as, for example, legal history and legal ethics.

It is sometimes overlooked that the source-book may be used for different purposes. Langdell's idea was that the "law, considered as a science, consists of certain principles or doctrines," and his purpose was to teach these doctrines by showing their historical unfoldment in concrete cases. ${ }^{11}$ His object was simply to give information through a method superior to the text-book. Later, the notion was advanced that the object of law-school training primarily is not to provide information but to develop the "power of legal reasoning." There is a certain vagueness about this formula which makes its reception easy, since it means all things to all men. Whatever the purpose or the method, information and training can never be avoided as ultimate objects. Classification, therefore, must proceed upon another basis. The source-book may be used: (1) to show the historical unfoldment of legal rules, where the student must discern from case to case, presented in historical sequence, wherein and to what extent the rule found in an earlier case has been modified; (2) to afford training in generalization from a sufficient number of dissimilar concrete instances which involve specific applications; for this purpose, in strict method, the cases should not embody historical variationsin other words, the phenomena to be studied should belong to the same legal epoch; (3) to afford training in reconciling apparent differences; (4) to afford training in critical construction of legal rules in the light of data given by concrete instances; this method differs from (2) in that the whole field of law is drawn upon in order to make the constructions arrived at harmonize as far as possible with the law considered as a system; (5) to afford training in the methods of reaching legal conclusions apart from the rules; (6) to afford material for critical inquiries as to legal policy; (7) for purposes of comparative law, i. e., different legal systems contrasted either in substance (rules, doctrines) or in form (methods of technical operation).

The first three of these objects are measurably attainable without the aid of formal or analytical jurisprudence. The others without a juristic medium of exchange are an intellectual impossi-

11 Select Cases on Contracts, Boston, 1871, p. vi (preface). 
bility, however much we may lay the flattering unction to our souls that we are teaching law in a rigidly scientific manner. ${ }^{12}$

The problem of jurisprudence studies is not logically connected with the case method of study nor is it related except historically to the sources of Anglo-American law. The fact that the bulk of our law is found in cases has made necessary pedagogically the study of cases at first hand. The nature of the sources has also no doubt fostered an empirical attitude toward the system as a whole, but there is no logical connection. There is just as much room for legal science in the Anglo-American system as in the Roman system, and perhaps more need. The fact that the codified form of Roman law leads up naturally to deductive studies, is irrelevant, except as a predisposing historical fact. And when the pedagogical utility of deductive methods of study is called in question, we need only recall that in European countries there have always been found, and are still to be found, not only jurists but lawyers.

The point of the discussion is this - the university law school must continue its old effectiveness, ${ }^{13}$ but it must do more; it must hold up the torch of legal learning; it must prepare its men not only to be skillful practitioners so far as it may be able, but men of understanding. The legal profession will never want skillful practitioners; such men were developed in abundance and no doubt will continue to be developed without the aid of the university law school. The future is one of legislation. Precedent has had its day. If this legislation and the application of it are to escape the empirical tradition which is now out of its time, there must be a change in the training of those lawyers who are to take part in constructing our legal future in the halls of the legislature, at the bar, and in the chambers of the judge. A continuation of an

\footnotetext{
12 These two divisions correspond to what Ihering contrasted as lower (or receptive) and higher (or productive) jurisprudence: Ihering, Geist d. röm. Rechts, III, 358.

18 It would not be very difficult to prove that what is most valuable in the present methods of teaching is based not on a superficial matching of cases, but on juristic analysis. The same is true of the best legal writing. Eliminate the jurisprudence attitude and there is nothing left. The best teachers, like the ablest practicing lawyers, develop a scientific method of dealing with legal materials through superior mental endowment, but the path of development is a rugged and uneven one. There is a certain virtue in this hand-to-mouth approach to legal science, but the disadvantages clearly preponderate against the advantages. If it were thought desirable to insist that legal science should come to the law student by a process of pure selfdevelopment, then for consistency we should once in each generation retire all men of science and destroy all scientific literature, in order that the beatitude of a masterful inefficiency might be fully realized.
} 
exclusive empirical tradition will not be found adequate. If there is such a thing as jurisprudence or legal science, it must be taught and studied, and there is only one place where that teaching and that study can be effectually prosecuted-the law school; and it will not be effectively taught and studied until the undergraduate participates in it, to the extent, at least, that may be necessary to give our system of law a scientific outlook. The view that jurisprudence is not for the law-school undergraduate, like the theory of imperial Roman law, would have legal science come from the top downward; on the contrary, like the lex terrae which comes from below upwards, the undergraduate school should build up and fertilize the graduate school and research. It will be a reproach to our system of education if we shall always be compelled to import our legal science from France, Germany, Holland, Italy, or Switzerland. We can stand alone, but if it is better to stand together, we can at least stand as equals, giving as much as we receive.

The case-book was a remarkable invention. It may be regarded as a permanent contribution. But multiplication of the Ames case-book does not multiply legal science. If legal education is to make any advance, it must again strike out in new directions. This new movement will involve, as it seems to us, the following points of departure:

1. The curriculum must be reorganized on a unified plan. This will require also a rearrangement of classroom materials.

2. It must be recognized that different approaches are necessary at different stages in the study of the law. As the method now stands, the same methods are employed throughout the law-school course. Only the objects differ.

3. Jurisprudence, and especially what are called formal and analytical jurisprudence, must be the basis of reconstruction.

Northwestern University, Albert Kocourek. Chicago, Illinois. 